(C) 2014

Козечко В. І., стариий викладач

Дніпропетровський державний аграрно-економічний університет

\title{
ВПЛИВ ТЕХНОЛОГІЧНИХ ПРИЙОМІВ ВИРОЩУВАННЯ НА ФОРМУВАННЯ ПОКАЗНИКІВ ЯКОСТІ ЗЕРНА ПШЕНИЦІ ОЗИМОЇ В УМОВАХ ПІВНІЧНОГО СТЕПУ
}

\section{Рецензент - доктор сільськогосподарських наук О. П. Якунін}

Результати проведених експериментальних досліджень свідчать, що за вирощування різних сортів пшениці озимої після ріпаку ярого в умовах північного Степу Украйни одержання найбільш якісного зерна (третього класу якості) забезпечує сівба 25 вересня та 5 жовтня. Сівба 5 та 15 вересня забезпечувала одержання зерна, здебільшого, n'ятого й четвертого класів якості. Із-поміж досліджуваних сортів пшениці озимої найбільшим вмістом білку (11,2-13,0 \%) $i$ клейковини (17,5-22,7 \%) у зерні вирізнявся сорт Селянка. Найменшими ці показники були у сорту Подолянка - 10,6-12,5 та 17,1-21,9\% відповідно. Об'єм хліба, отриманого з борошна пшениці озимої сорту Селянка, був найвищим. Так, у середньому за 20082010 рр. він коливався від 495 cм $^{3}$ за сівби 5 вересня нормою висіву 4 млн схожих насінин/га до $612 \mathrm{~cm}^{3}$ за сівби 5 жовтня иією ж нормою. Встановлено вплив норм висіву насіння на показники якості зерна. Так, найвищий вміст білку $і$ клейковини в зерні, а також об'см хліба відмічено на варіантах досліду, де сівбу проводили нормою 4 млн схожих насінин/га. Збільшення норми висіву призводило до зменшення даних показників. У середньому за роки досліджень найвищу врожайність формував сорт Селянка $(4,89 \mathrm{~m} / 2 a)$ за сівби 25 вересня нормою 5 млн схожсих насінин/га. Максимальну врожайність рослини сорту Золотоколоса - 4,20 та 4,19 m/2а - формували, відповідно, за сівби 5 жовтня нормою 6 млн схожих насінин/га та 25 вересня нормою висіву 5 млн схожих насінин/га. Найнижчу серед сортів урожайність формував сорт Подолянка, щзо коливалася за період проведення досліджень у межах 2,99-3,75 m/2а.

Ключові слова: пшениия озима, сорт, строк сівби, норма висіву, якість зерна, урожайність.

Постановка проблеми. Північний Степ України здавна вважався одним із найсприятливіших регіонів для одержання високоякісного зерна пшениці озимої - основної зернової культури нашої держави. Особливості кліматичних умов зони Степу, які характеризуються низькою кількістю опадів протягом року, частими посухами, вимагають від сільськогосподарських товаровиробників сумлінного дотримання рекомендацій iз вирощування пшениці озимої, що передбачають послідовне виконання агротехнічних захо- дів. Останнім часом, на жаль, у зв'язку зі змінами в структурі посівних площ, зумовлених реформацією ринкової економіки, все частіше спостерігається порушення товаровиробниками рекомендацій наукових установ щодо вирощування цієї культури. Це полягає в проведенні сівби після невивчених попередників, зокрема ріпаку ярого. Водночас поступові зміни клімату в бік потепління, яке відмічають останнім часом на території України, а також більш інтенсивний розвиток сучасних сортів пшениці, біологічні особливості яких ще недосліджені, спонукають аграрну науку до удосконалення існуючих і розробки нових агроприйомів вирощування цієї культури.

Аналіз останніх досліджень і публікацій, у яких започатковано розв'язання проблеми. Уже тривалий час науковці проводять дослідження 3 вивчення впливу технологічних прийомів вирощування на якість зерна. За свідченням багатьох науковців, вміст білку і клейковини в зерні зростає за вирощування пшениці озимої в умовах підвищених температур і помірного дефіциту вологи [4, 11].

Дослідники в своїх роботах зазначають суттєвий вплив на вміст білку та клейковини в зерні попередників, рівня мінерального живлення рослин [7], а також високу ефективність від застосування бакових сумішок азотних добрив та інсектицидів за обробки рослин, що забезпечує одержання у вирощуванні після непарових попередників в умовах Степу зерна 2-3-го класу якості [3].

У наукових працях вітчизняних вчених зазначається залежність показників якості зерна від сорту, рівня вологозабезпечення, захисту рослин, підживлень і доз добрив $[1,5,6,12]$.

Водночас у науковій літературі відсутні публікації з результатами досліджень із вивчення строків сівби і норм висіву сучасних сортів пшениці озимої за вирощування ії після ріпаку ярого в умовах північного Степу України. Вивчення даних питань дасть змогу визначити параметри формування якості зерна різними сортами пшениці озимої в разі вирощування після ріпаку ярого. 


\section{СІЛЬСЬКЕ ГОСПОДАРСТВО. РОСЛИННИЦТВО}

Мета і завдання досліджень. Метою проведених досліджень була розробка більш досконалих технологічних прийомів вирощування високоякісного зерна пшениці озимої за сівби після ріпаку ярого за різних строків сівби й норм висіву насіння.

Завдання досліджень полягало у визначенні факторів впливу на підвищення показників якості зерна різних сортів пшениці озимої в умовах недостатнього зволоження північного Степу України.

Матеріали і методи досліджень. Польові досліди проводили на дослідному полі Дніпропетровського державного аграрного університету (нині - Дніпропетровський державний аграрноекономічний університет) у 2007-2010 рр. відповідно до загальноприйнятих методик [8, 9]. Грунтовий покрив дослідних ділянок представлений чорноземами звичайними малогумусними та повнопрофільними. Вміст легкогідролізованого азоту (за Тюріним і Коконовою) в шарі грунту 0-20 см становить $8,0-8,5$ мг/100 г грунту, рухомого фосфору (за Чиріковим) - 9,0-10,0, обмінного калію (за Масловою) - 14,0-15,0 мг/100 г грунту. Реакція грунтового розчину - близька до нейтральної, $\mathrm{pH}-6,8-7,0$. У дослідах вирощували сорти пшениці озимої Золотоколоса, Селянка, Подолянка. Попередник - ріпак ярий. Норми висіву насіння - 4, 5 та 6 млн схожих насінин/га. Сіяли сівалкою СН-16 у чотири строки: $5,15,25$ вересня і 5 жовтня. Технологія вирощування пшениці озимої (крім поставлених на вивчення питань) була загальноприйнятою для північного Степу України. Повторність у дослідах - триразова, розміщення ділянок послідовне, систематичне, посівна площа однієї ділянки - 80 м², облікова - $60 \mathrm{~m}^{2}$. Облік урожаю проводили методом суцільного обмолоту всієї площі облікової ділянки комбайном Sampo-500 (пряме комбайнування) за повної стиглості зерна. Статистичну обробку даних урожайності пшениці озимої проводили на ПК методом дисперсійного аналізу за Б. О. Доспєховим [2].

Результати досліджень. Біокліматичні ресурси північного Степу є достатньо сприятливими для одержання зерна пшениці озимої високої якості. За період проведення досліджень гідротермічні показники суттєво відрізнялися від середніх багаторічних, тому умови для вегетації озимини були неоднорідними. Так, наприклад, річна кількість атмосферних опадів у 2007/08 вегетаційному році перевищувала середню багаторічну норму (514 мм) на 10 мм $(1,9 \%)$, у 2009/10 p. - на 183,7 мм (26,3\%). У 2008/09 р. кількість опадів була на 7,9 мм, або на $1,5 \%$ нижчою, порівняно з середніми багаторічними значеннями даного показника. Разом із тим темпера- турний режим повітря у 2007/08 перевищував багаторічну норму на $0,2^{\circ} \mathrm{C}$, у 2008/09 та 2009/10 pр. - на 0,7 та $3,6^{\circ} \mathrm{C}$ відповідно.

До основних показників якості зерна пшениці озимої, передусім, слід віднести вміст у ньому білку, клейковини та іï властивостей, а також таких хлібопекарських показників якості, як об'єм хліба та його пористість.

У літературних джерелах, за даними багаторічних спостережень на сортодільницях, вказується, що кількість білку в зерні пшениці озимої може коливатися в межах від 8,4 до 17,6\% [13]. Наші дослідження з метою визначення показників якості зерна різних сортів пшениці озимої дозволили виявити певні залежності їх зміни від дії агротехнічних прийомів, які вивчали, та погодних умов, що складалися в період проведення досліджень (табл. 1).

Одержані експериментальні дані свідчать, що кількість білку в зерні пшениці залежала від багатьох факторів, зокрема, від сорту. Серед сортів, які вивчалися нами у дослідах, найбільшим вміст білку в зерні відмічено у сорту Селянка. Залежно від норми висіву за сівби 5 вересня вміст білку коливався в межах 11,2-12,1\%, 15 вересня - 11,4-12,3\%, 25 вересня - 12,0-12,8 \%, 5 жовтня - 12,2-13,0\%. Найменшою частка білку в зерні була відмічена у сорту Подолянка - 10,6-11,3\%, 11,2-11,6\%, 11,8-12,3\% та 11,9-12,5\% відповідно за сівби в ці терміни.

Найбільшу кількість білку сорти пшениці озимої формували в умовах 2009 р., коли відмічали випадання меншої кількості опадів за вегетаційний період озимини та формування меншого за розмірами врожаю зерна. Більше накопичення білку у зерні пшениці в цей рік пояснюється більш посушливими умовами, порівняно з іншими роками досліджень у період його дозрівання. Так, кількість опадів у червні становила тільки 16,0 мм $(25,8 \%$ середньобагаторічної місячної норми). За сприятливіших умов зволоження, які відмічали в 2008 та 2010 рр., вміст білку у сортів пшениці озимої був значно меншим.

Встановлено, що на кількість білку в зерні суттєвий вплив мали строки сівби пшениці озимої. Майже на всіх ділянках досліду рослини за сівби 25 вересня та 5 жовтня формували більш якісне за вмістом білку зерно. В середньому за 2008-2010 pp. у сорту Золотоколоса за сівби 25 вересня, залежно від норм висіву насіння, вміст білку в зерні становив 11,9-12,5 \%, у сорту Селянка - 12,0-12,8\%, у сорту Подолянка $11,8-12,3 \%$. За сівби 5 жовтня у зазначених сортів - 12,1-12,6\%, 12,2-13,0\% та $11,9-12,5 \%$ відповідно. 
СІЛЬСЬКЕ ГОСПОДАРСТВО. РОСЛИННИЦТВО

\section{1. Вміст білку в зерні різних сортів пиениці озимої (\%) залежно від строків сівби та норм висіву насіння, 2008-2010 рр.}

\begin{tabular}{|c|c|c|c|c|c|}
\hline \multirow{2}{*}{ Строк сівби } & \multirow{2}{*}{$\begin{array}{l}\text { Норма висіву, млн } \\
\text { схожих насінин/га }\end{array}$} & \multicolumn{3}{|c|}{ Роки } & \multirow{2}{*}{ Середнє } \\
\hline & & 2008 & 2009 & 2010 & \\
\hline \multicolumn{6}{|c|}{ сорт Золотоколоса } \\
\hline \multirow{3}{*}{5 вересня } & 4 & 11,1 & 11,8 & 11,3 & 11,4 \\
\hline & 5 & 11,0 & 11,3 & 11,0 & 11,1 \\
\hline & 6 & 10,8 & 11,0 & 10,9 & 10,9 \\
\hline \multirow{3}{*}{15 вересня } & 4 & 11,5 & 12,1 & 11,6 & 11,7 \\
\hline & 5 & 11,3 & 11,6 & 11,3 & 11,4 \\
\hline & 6 & 10,9 & 11,8 & 11,2 & 11,3 \\
\hline \multirow{3}{*}{25 вересня } & 4 & 12,1 & 13,1 & 12,3 & 12,5 \\
\hline & 5 & 11,6 & 12,8 & 11,7 & 12,0 \\
\hline & 6 & 11,5 & 12,6 & 11,6 & 11,9 \\
\hline \multirow{3}{*}{5 жовтня } & 4 & 12,2 & 13,2 & 12,4 & 12,6 \\
\hline & 5 & 11,8 & 12,9 & 11,9 & 12,2 \\
\hline & 6 & 11,6 & 12,8 & 11,8 & 12,1 \\
\hline \multicolumn{6}{|c|}{ сорт Селянка } \\
\hline \multirow{3}{*}{5 вересня } & 4 & 11,7 & 12,5 & 12,0 & 12,1 \\
\hline & 5 & 11,2 & 12,4 & 11,3 & 11,6 \\
\hline & 6 & 10,8 & 11,9 & 10,9 & 11,2 \\
\hline \multirow{3}{*}{15 вересня } & 4 & 12,0 & 12,8 & 12,2 & 12,3 \\
\hline & 5 & 11,4 & 12,7 & 11,5 & 11,9 \\
\hline & 6 & 11,0 & 12,1 & 11,1 & 11,4 \\
\hline \multirow{3}{*}{25 вересня } & 4 & 12,6 & 13,2 & 12,7 & 12,8 \\
\hline & 5 & 11,9 & 13,0 & 12,1 & 12,3 \\
\hline & 6 & 11,5 & 12,5 & 12,0 & 12,0 \\
\hline \multirow{3}{*}{5 жовтня } & 4 & 12,7 & 13,5 & 12,9 & 13,0 \\
\hline & 5 & 12,0 & 13,1 & 12,3 & 12,5 \\
\hline & 6 & 11,6 & 12,7 & 12,3 & 12,2 \\
\hline \multicolumn{6}{|c|}{ сорт Подолянка } \\
\hline \multirow{3}{*}{5 вересня } & 4 & 11,1 & 11,6 & 11,3 & 11,3 \\
\hline & 5 & 11,0 & 11,2 & 11,0 & 11,1 \\
\hline & 6 & 10,5 & 10,8 & 10,6 & 10,6 \\
\hline \multirow{3}{*}{15 вересня } & 4 & 11,4 & 12,0 & 11,5 & 11,6 \\
\hline & 5 & 11,2 & 11,5 & 11,2 & 11,3 \\
\hline & 6 & 10,8 & 11,7 & 11,1 & 11,2 \\
\hline \multirow{3}{*}{25 вересня } & 4 & 12,0 & 12,8 & 12,1 & 12,3 \\
\hline & 5 & 11,5 & 12,5 & 11,6 & 11,9 \\
\hline & 6 & 11,3 & 12,5 & 11,6 & 11,8 \\
\hline \multirow{3}{*}{5 жовтня } & 4 & 12,1 & 13,0 & 12,3 & 12,5 \\
\hline & 5 & 11,7 & 12,7 & 11,8 & 12,1 \\
\hline & 6 & 11,5 & 12,6 & 11,7 & 11,9 \\
\hline
\end{tabular}

Норми висіву насіння, визначаючи густоту стояння рослин у посівах, також впливали на накопичення білку в зерні. Встановлено, що сорти формували більший вміст білку в зерні на варіантах досліду, де сівбу пшениці озимої проводили нормою висіву 4 млн схожих насінин/га. Збільшення норми сприяло зменшенню вмісту білку в зерні рослин. Так, підвищення норми висіву з 4 до 6 млн схожих насінин/га у сорту Селянка призводило до зменшення білковості зерна за сівби 5 вересня - на 7,4 \%, 15 вересня - на 7,3\%. На ділянках досліду, де пшеницю висівали 25 вересня та 5 жовтня, ця різниця становила 6,3 та 6,2 \% відповідно. Аналогічна тенденція спостерігалась у сортів Золотоколоса та Подолянка. 
СІЛЬСЬКЕ ГОСПОДАРСТВО. РОСЛИННИЦТВО

\section{2. Вміст клейковини в зерні різних сортів пиениці озимої залежно від строків сівби та норм висіву насіння (\%), 2008-2010 рр.}

\begin{tabular}{|c|c|c|c|c|c|}
\hline \multirow{2}{*}{ Строк сівби } & \multirow{2}{*}{$\begin{array}{l}\text { Норма висіву, млн } \\
\text { схожих насінин/га }\end{array}$} & \multicolumn{3}{|c|}{ Роки } & \multirow{2}{*}{ Середнє } \\
\hline & & 2008 & 2009 & 2010 & \\
\hline \multicolumn{6}{|c|}{ сорт Золотоколоса } \\
\hline \multirow{3}{*}{5 вересня } & 4 & 17,0 & 18,0 & 17,8 & 17,6 \\
\hline & 5 & 16,9 & 17,9 & 17,4 & 17,4 \\
\hline & 6 & 16,8 & 17,7 & 17,3 & 17,3 \\
\hline \multirow{3}{*}{15 вересня } & 4 & 17,4 & 18,1 & 17,9 & 17,8 \\
\hline & 5 & 17,2 & 18,2 & 17,9 & 17,8 \\
\hline & 6 & 17,0 & 18,0 & 17,7 & 17,6 \\
\hline \multirow{3}{*}{25 вересня } & 4 & 18,5 & 20,3 & 19,2 & 19,3 \\
\hline & 5 & 18,3 & 19,8 & 18,3 & 18,8 \\
\hline & 6 & 18,2 & 18,8 & 18,8 & 18,6 \\
\hline \multirow{3}{*}{5 жовтня } & 4 & 21,7 & 23,4 & 22,2 & 22,4 \\
\hline & 5 & 21,5 & 23,2 & 21,8 & 22,2 \\
\hline & 6 & 20,6 & 22,6 & 21,1 & 21,4 \\
\hline \multicolumn{6}{|c|}{ сорт Селянка } \\
\hline \multirow{3}{*}{5 вересня } & 4 & 17,4 & 18,2 & 17,9 & 17,8 \\
\hline & 5 & 17,3 & 18,0 & 17,7 & 17,7 \\
\hline & 6 & 17,1 & 17,8 & 17,6 & 17,5 \\
\hline \multirow{3}{*}{15 вересня } & 4 & 17,5 & 18,3 & 18,0 & 17,9 \\
\hline & 5 & 17,4 & 18,2 & 17,9 & 17,8 \\
\hline & 6 & 17,3 & 18,1 & 17,8 & 17,7 \\
\hline \multirow{3}{*}{25 вересня } & 4 & 18,6 & 20,5 & 19,5 & 19,5 \\
\hline & 5 & 18,4 & 20,0 & 18,9 & 19,1 \\
\hline & 6 & 18,3 & 18,9 & 18,8 & 18,7 \\
\hline \multirow{3}{*}{5 жовтня } & 4 & 22,3 & 23,5 & 22,4 & 22,7 \\
\hline & 5 & 21,9 & 23,3 & 22,1 & 22,4 \\
\hline & 6 & 21,2 & 23,2 & 21,4 & 21,9 \\
\hline \multicolumn{6}{|c|}{ сорт Подолянка } \\
\hline \multirow{3}{*}{5 вересня } & 4 & 16,9 & 17,9 & 17,6 & 17,5 \\
\hline & 5 & 16,7 & 17,8 & 17,3 & 17,3 \\
\hline & 6 & 16,6 & 17,6 & 17,1 & 17,1 \\
\hline \multirow{3}{*}{15 вересня } & 4 & 17,3 & 18,2 & 17,7 & 17,7 \\
\hline & 5 & 17,0 & 18,0 & 17,6 & 17,5 \\
\hline & 6 & 16,9 & 17,9 & 17,5 & 17,4 \\
\hline \multirow{3}{*}{25 вересня } & 4 & 18,4 & 18,7 & 18,9 & 18,7 \\
\hline & 5 & 18,2 & 19,4 & 18,3 & 18,6 \\
\hline & 6 & 18,1 & 18,3 & 18,1 & 18,2 \\
\hline \multirow{3}{*}{5 жовтня } & 4 & 21,2 & 22,8 & 21,8 & 21,9 \\
\hline & 5 & 20,8 & 22,6 & 21,3 & 21,6 \\
\hline & 6 & 20,5 & 22,5 & 20,8 & 21,3 \\
\hline
\end{tabular}

Як відомо, борошно, отримане із зерна пшениці озимої, повинно мати здатність створювати тісто, яке б мало необхідні фізичні властивості 3 високою еластичністю, розтяжністю та значною здатністю поглинати воду [10].

Вміст клейковини в зерні різних сортів пшениці озимої визначався також умовами вирощу- вання й залежав від сортових особливостей рослин, строків сівби та норм висіву насіння. Найбільше клейковини містилося в зерні пшениці озимої сорту Селянка. Залежно від норми висіву iї кількість становила за сівби 5 вересня - 17,5$17,8 \%, 15$ вересня - 17,7-17,9\%, 25 вересня $18,7-19,5 \%, 5$ жовтня - 21,9-22,7\%. 
СІЛЬСЬКЕ ГОСПОДАРСТВО. РОСЛИННИЦТВО

\section{3. Об'єм хліба, випеченого з зерна різних сортів пшениці озимої, залежно від строків сівби та} норм висіву насіння $\left(\mathrm{cm}^{3}\right), 2008-2010 \mathrm{pp}$.

\begin{tabular}{|c|c|c|c|c|c|}
\hline \multirow{2}{*}{ Строк сівби } & \multirow{2}{*}{$\begin{array}{l}\text { Норма висіву, млн } \\
\text { схожих насінин/га }\end{array}$} & \multicolumn{3}{|c|}{ Роки } & \multirow{2}{*}{ Середнє } \\
\hline & & 2008 & 2009 & 2010 & \\
\hline \multicolumn{6}{|c|}{ сорт Золотоколоса } \\
\hline \multirow{3}{*}{5 вересня } & 4 & 530 & 572 & 547 & 550 \\
\hline & 5 & 469 & 553 & 491 & 504 \\
\hline & 6 & 442 & 548 & 472 & 487 \\
\hline \multirow{3}{*}{15 вересня } & 4 & 536 & 580 & 554 & 557 \\
\hline & 5 & 472 & 560 & 499 & 510 \\
\hline & 6 & 450 & 554 & 479 & 494 \\
\hline \multirow{3}{*}{25 вересня } & 4 & 580 & 603 & 584 & 589 \\
\hline & 5 & 519 & 575 & 509 & 534 \\
\hline & 6 & 504 & 559 & 513 & 525 \\
\hline \multirow{3}{*}{5 жовтня } & 4 & 600 & 615 & 605 & 607 \\
\hline & 5 & 543 & 584 & 552 & 560 \\
\hline & 6 & 514 & 580 & 524 & 539 \\
\hline \multicolumn{6}{|c|}{ сорт Селянка } \\
\hline \multirow{3}{*}{5 вересня } & 4 & 539 & 580 & 554 & 558 \\
\hline & 5 & 476 & 560 & 500 & 512 \\
\hline & 6 & 449 & 556 & 479 & 495 \\
\hline \multirow{3}{*}{15 вересня } & 4 & 550 & 585 & 560 & 565 \\
\hline & 5 & 480 & 565 & 505 & 517 \\
\hline & 6 & 455 & 560 & 485 & 500 \\
\hline \multirow{3}{*}{25 вересня } & 4 & 585 & 610 & 590 & 595 \\
\hline & 5 & 525 & 580 & 515 & 540 \\
\hline & 6 & 510 & 565 & 520 & 532 \\
\hline \multirow{3}{*}{5 жовтня } & 4 & 605 & 620 & 610 & 612 \\
\hline & 5 & 550 & 590 & 560 & 567 \\
\hline & 6 & 520 & 585 & 530 & 545 \\
\hline \multicolumn{6}{|c|}{ сорт Подолянка } \\
\hline \multirow{3}{*}{5 вересня } & 4 & 527 & 568 & 542 & 546 \\
\hline & 5 & 465 & 549 & 486 & 500 \\
\hline & 6 & 437 & 544 & 467 & 483 \\
\hline \multirow{3}{*}{15 вересня } & 4 & 520 & 565 & 550 & 545 \\
\hline & 5 & 480 & 540 & 510 & 510 \\
\hline & 6 & 450 & 535 & 475 & 487 \\
\hline \multirow{3}{*}{25 вересня } & 4 & 565 & 580 & 575 & 573 \\
\hline & 5 & 510 & 560 & 515 & 528 \\
\hline & 6 & 500 & 545 & 510 & 518 \\
\hline \multirow{3}{*}{5 жовтня } & 4 & 585 & 600 & 605 & 597 \\
\hline & 5 & 530 & 580 & 540 & 550 \\
\hline & 6 & 510 & 570 & 535 & 538 \\
\hline
\end{tabular}

У сорту Подолянка вміст клейковини в зерні був найменшим i, залежно від строків сівби та норм висіву, складав 17,1-21,9\% (табл. 2). Рослини всіх сортів, які ми вивчали в дослідах, формували більше клейковини в зерні за сівби 25 вересня та 5 жовтня. Найменшими значеннями даного показника вирізнялися варіанти до- сліду, де сівбу пшениці проводили 5 вересня.

Якість клейковини у зерні, яке отримали 3 дослідних ділянок, залежно від сорту, строків сівби та норм висіву мала високі показники, згідно 3 діючими стандартами якості. Дослідженнями встановлено, що посіви раннього строку сівби (5 вересня) мали більш розмиту клейковину (по- 


\section{СІЛЬСЬКЕ ГОСПОДАРСТВО. РОСЛИННИЦТВО}

над 75 одиниць), а більш пізні (25 вересня та 5 жовтня), навпаки, більш пружну (50-75 одиниць). Краща якість клейковини у зерні формувалася в умовах 2009 року, порівняно із зерном, яке отримували у 2008 та 2010 роках.

У 2008 та 2010 рр. якість клейковини була значно гіршою, що можна пояснити більш вологими умовами у період дозрівання зерна, більшим рівнем урожайності, а також істотним пошкодженням посівів шкідливою черепашкою. Показники ВДК становили від 67 до 95 одиниць. У визначенні індексу деформації клейковини не було помічено суттєвої різниці у величині одержаних показників по ділянках досліду, де пшеницю озиму висівали з різними нормами висіву. Однак, на варіантах, де пшеницю висівали 3 нормою висіву 6 млн схожих насінин/га, тобто на більш загущених посівах, індекс деформації клейковини був на 2-5 одиниць вищим.

Основними показниками у визначенні придатності зерна для продовольчих цілей $є$ його хлібопекарські властивості, зокрема, об'єм хліба (табл. 3).

У наших дослідах на хлібопекарські показники якості зерна пшениці озимої значно впливали, перш за все, вміст у зерні білку та клейковини, пружність клейковини, а також його хімічний склад. Усі вказані показники, згідно з отриманими нами даними, залежали від агротехнічних факторів, що вивчали, та погодних умов у роки проведення досліджень.

Найбільш якісне за хлібопекарськими показниками зерно формували рослини пшениці в 2009 році. Об'єм хліба, отриманого з борошна пшениці озимої сорту Селянка, був найвищим. Так, у середньому за 2008-2010 рр. він коливався від $495 \mathrm{~cm}^{3}$ за сівби 5 вересня нормою висіву 4 млн схожих насінин/га до $612 \mathrm{~cm}^{3}-$ за сівби 5 жовтня цією ж нормою. Найбільший об' $є$ м хліба відмічено при випіканні з борошна зерна, отриманого на ділянках досліду, де сівбу озимини проводили в середині першої декади жовтня.

\section{БІБЛІОГРАФІЯ}

1. Гасанова I. I. Якість зерна нових сортів пшениці озимої в північному Степу України / I. I. Гасанова, Н. Л. Криворучко // Матеріали VIII Міжнародної науково-практичної конференції «Найновите научни постижения - 2012». - Болгарія, 2012. - С. 40-42.

2. Доспехов Б.А. Методика опытного дела / Б. А. Доспехов. - М. : Колос, 1985. - 336 с.

3. Заходи підвищення урожайності та якості зерна озимої пшениці в умовах Присивашшя / I. I. Гасанова, I. В. Костиря, М. А. Остапенко [та ін.]
Значний вплив на хлібопекарські показники якості мали також і норми висіву насіння. В середньому за роки проведення досліджень найбільший об'єм хліба забезпечувало зерно, одержане 3 посівів, які висівали 3 нормою 4 млн схожих насінин/га. Збільшення норм висіву призводило до зниження об’ єму хліба.

Рівень урожайності різних сортів пшениці озимої в наших дослідах залежав від строків сівби та норм висіву насіння. В середньому за роки проведення досліджень найвищу врожайність (4,89 т/га) сформували рослини сорту Селянка, сівбу якого проводили в середині третьої декади вересня (25 вересня) 3 нормою висіву 5 млн схожих насінин/га. Зернова продуктивність сорту Золотоколоса була нижчою, ніж у сорту Селянка, - максимальні iї показники (4,20 т/га) відмічено за сівби 5 жовтня нормою висіву 6 млн схожих насінин/га та 25 вересня нормою 5 млн схожих насінин/га (4,19 т/га). Найнижчу серед сортів урожайність формував сорт Подолянка, що коливалася за період проведення досліджень у межах 2,99-3,75 т/га. Найвищі врожайні показники даного сорту $(3,75$ т/га) відмічено за сівби 5 жовтня нормою 6 млн схожих насінин/га.

Висновок. Таким чином, у процесі вирощування після ріпаку ярого найбільш якісне зерно формували посіви пшениці озимої, яку висівали 25 вересня та 5 жовтня. Зерно на даних варіантах досліду відповідало переважно третьому класу якості. Сівба 5 та 15 вересня забезпечувала одержання зерна, здебільшого, п'ятого й четвертого класів якості.

Найбільший вміст білку і клейковини в зерні, а також об'єм хліба, всі сорти формували за сівби 25 вересня та 5 жовтня. За даними показниками найкращою якістю зерна 3-поміж досліджуваних сортів вирізнявся сорт Селянка. Урожайність цього сорту, в середньому за роки проведення досліджень, виявилася також найвищою $(4,89$ т/га) за сівби 25 вересня нормою 5 млн схожих насінин/га.

// Бюлетень Інсититуту сільського господарства степової зони НААН України. - Д. : Нова ідеологія, 2012. - №2. - С. 98-102.

4. Коданев И. М. Повышение качества зерна / И. М. Коданев. - М. : Колос, 1976. - 304 с.

5. Конопльова С. Л. Ефективність заходів підвищення урожайності та якості зерна пшениці озимої по попереднику чорний пар у північному Степу України / Є. Л. Конопльова // Бюлетень Інституту сільського господарства степової зони НААН України. - Д. : Нова ідеологія, 2012. - 
№3. - C. 99-103.

6. Конопльова $С$. Л. Ефективність вирощування пшениці озимої залежно від технологічних заходів в північному Степу України / Є. Л. Конопльова // Агробіологія : зб. наук. праць. - Біла Церква, 2012. - Випуск 7 (91). - С. 117-120.

7. Костиря I. B. Урожайність зерна пшениці озимої та рівень його якості залежно від попередників і системи удобрення в умовах Присивашшя / І. В. Костиря // Зрошуване землеробство : міжвід. тем. наук. зб. - Херсон : Айлант, 2012. Вип. 58. - С. 51-53.

8. Методические рекомендации по проведению полевых опытов с зерновыми, зернобобовыми и кормовыми культурами / [Под ред. В. С. Цыкова и Г. Р. Пикуша]. - Днепропетровск, 1983. $-46 \mathrm{c}$.

9. Методика державного сортовипробування с.-г. культур / [за ред. В. В. Вовкодава; випуск другий]. - К., 2001. - 65 с.

10. Озимі зернові культури / [За редакцією Л. О. Животкова, С. В. Бірюкова]. - К. : Урожай. $-1993 .-288 \mathrm{c}$.

11. Созинов A. А. Улучшение качества зерна озимой пшеницы и кукурузы / Созинов А. А., Жемела Г. П. - М. : Колос , 1983. - 270 с.

12. Солодушко М. М. Вплив мінерального живлення на якість зерна пшениці озимої в північному Степу / М. М. Солодушко, I. I. Гасанова, I. I. Середа // Матеріали науково-практичної конференції молодих учених і спеціалістів: «Агротехнології для сталого виробництва конкурентоспроможної продукції». - Чабани, 2012. - C. 61-62.

13. Шулындин А. Ф. Пути повышения содержания белка в зерне пшеницы / А. Ф. Шулындин // Селекция и семеноводство. - 1974. - № 3. - С. 15-19. 